\title{
The Culture of Construction Organisations: the Epitome of Institutionalised Corruption
}

\author{
Andrew Oyen Arewa ${ }^{1}$ and Peter Farrell ${ }^{2}$ \\ ${ }^{1}$ Department of Civil Engineering, Architecture and Building Faculty of Engineering and Computing, Coventry \\ University, UK \\ ${ }^{2}$ School of Engineering, University of Bolton, UK
}

\begin{abstract}
The culture of an organisation is a vital element of business competency that must align with its strategic goals, and enhance peoples' perceptions, feelings and behaviour in adapting to the world around them. Organisational culture may also bring about negative practices such as dishonesty and unethical behaviours. Recently the culture of some construction organisations has been called into question. For example, major construction projects around the globe have become involved in allegations of fraud and corruption. The cost is currently estimated at US $\$ 860$ billion globally; with forecasts that it may rise to US $\$ 1.5$ trillion by 2025 . Hitherto the role of the culture of construction organisations in fraud and corruption activities has been largely hidden. The study aim is to establish whether the culture of construction organisations promotes corrupt practices in the UK construction and infrastructure sector. The study employed mixed research methods with interviews supported by a questionnaire and an examination of five case studies in different countries. Findings show that the culture of construction organisations together with the nature of the industry promotes fraud and corruption. The study subsequently highlights key cultural factors that support fraud and corruption in a way that is almost institutionalised.
\end{abstract}

Keywords: Construction, corruption, culture, organisations

Paper type: Research article

\section{Introduction}

Fraud and corruption is arguably a pervasive trait in doing business; and there is a growing worldwide concern over a high level of corrupt activities among corporate organisations. The nature and traits of fraud and corruption show that the acts are closely linked to culture, organisation values and beliefs that people hold. Arguably, the way construction organisations operate tends to make them vulnerable to corrupt practices. For example, the culture of most construction organisations is such that the use of lengthy supply chains and complex contractual arrangements are customary. Moreover, negotiation for commercial interest is a common practice in the construction and infrastructure sector. Thus, there are opportunities for clients, consultants, contractors, and suppliers to leverage payments or other benefits for private gain (Ernst and Young, 2012). Corruption may exist in the context of inappropriate activities of organisations with perhaps the knowledge of many individuals in those organisations, but with no personal gains. Corruption may also involve the activities of individuals who act for personal gain without the knowledge of their companies. Thus, the study aim is to establish whether the

Copyright: Construction Economics and Building 2015. (C) 2015 Andrew Oyen Arewa and Peter Farrell. This is an Open Access article distributed under the terms of the Creative Commons Attribution 4.0 Unported (CC BY 4.0) License (https://creativecommons.org/licenses/by/4.0/), allowing third parties to copy and redistribute the material in any medium or format and to remix, transform, and build upon the material for any purpose, even commercially, provided the original work is properly cited and states its license.

Citation: Arewa, A.O. and Farrell, P., 2015. The culture of construction organisations: the epitome of institutionalised corruption, Construction Economics and Building, 15(3), 59-71. DOI: http://dx.doi.org/10.5130/AJCEB.v15i3.4619

Corresponding author: Andrew Oyen Arewa; Email - ab6887@,coventry.ac.uk

Publisher: University of Technology Sydney (UTS) ePress 
culture of construction organisations promotes corrupt practices in the UK construction and infrastructure sector. The main objective of the study is to identify whether this culture of construction organisations supports corrupt practices in the construction industry.

Virtually all business dealings with corrupt traits in the construction industry have human and organisational aspects to them. Indeed the idea of corruption plays a powerful role in thinking about organisations and the behaviour of those entrusted with responsibilities (Levine, 2005). According to Transparency International (TI, 2006, p.5) "nowhere is corruption more ingrained than in the construction sector". The problem of corrupt practices in the sector seems to be exacerbated by the culture (the characteristics, knowledge of groups of people and organisational values) in the industry. Yet, research into the culture of construction organisations in the context of fraud and corruption are scarce. Harinarain et al (2013) asserts that the culture of organisations is powerful, and in most cases unconsciously forceful; it determines the behaviour of both individual and groups. Thus, it is vital to ascertain whether the culture of construction organisations influences apparent unending corrupt practices in construction.

Gates (2014) asserts that across industries, corruption is a major facet of business that most organisations have to face; and sadly it is under-reported as a distinctive problem. Most often, greed and a quest for quick profit are the major features driving corruption among companies (Stansbury, 2005). Some companies in construction may feel the need to devise means to avoid competition in order to maximise profit; a concept of economic rent. Construction businesses are project based, heavily influenced by clients and in most cases contracts are awarded based on tendering processes which emphasise lowest cost as the key selection criteria. Therefore, a tendency and temptation arises for processes to attract exploitation or bribery.

Most people believe that corruption is wrong. However, from an economic sense there is scepticism about whether businesses believe this is the case; considering the profit maximisation concept that underpins business values. An array of fraud and corruption cases in the last decade show that the act continues with a combination of individual, human and organisational effort. This is especially the case when huge amounts of money are involved. A discerning deduction from corruption cases around the globe is that people make up organisations and the culture of organisations has the potential to corrupt people. In practice the incentive that motivates individuals or corporate entities to behave in a corruption-prone manner is their perception of what can be gained easily by trying to take economic advantage of others.

Arguably, there is no universally accepted academic theory or model that relates the culture of organisations to corruption; though on a global scale corruption has been a key feature of institutions and organisations. Nevertheless it is only recently the theme of corruption has become the subject of sustained scientific analysis; and models that underpin the study of corruption only theorise why it occurs. The most likely theories that may help provide insight into the relationship between the culture of organisations and corruption-prone attitudes are economic concepts such as economic rent and profit maximisation theories. Indeed, these theories are important because the main objective of any business is to maximise profit, wealth or both. In a business sense, most organisations will achieve their objectives using quick and least costly means, regardless of altered forms.

For example, Lambsdorff (2001) in a research paper titled "Corruption in Empirical Research A Review" put forward theoretical insights of how institutional economics can be used to understand why corruption occurs and the best policies to combat it. But with a large rise in fraud cases and corruption in the last decade, there is a need to look beyond known causes. Thus there is a need to examine hidden factors such as the culture of organisations and the role of government as an institution or regulator. This is imperative because there is a growing number of fraud and corruption cases that dominate news headlines on a daily basis such as: the 2015 scandal at the Federation of International Football Association (FIFA); the pharmaceutical giant 
GlaxoSmithKline fraud of 2012 in the USA that led to a record fine of $\$ 3 \mathrm{BN}$ in the USA; and the Halliburton Plc bribery scandal that involved paying more than $\$ 6$ Billion to win a construction contract in the Nigeria Liquefied Natural - Gas project. All attest to the fact that fraud and corruption cases have organisational facets to them (Calkins, 2009; Runde et al, 2014).

The Grant Thornton International Ltd (GTIL, 2013, p.3) cited USA based Association of Certified Fraud Examiners (ACFE, 2013) to have claimed that "the cost of fraud and corruption in the construction industry is currently estimated at US\$860 billion globally; with the propensity of rising to US\$1.5 trillion by 2025". There are many examples of major construction projects that have come to completion with allegations of fraud and corruption. For example, the Sochi 2014 Winter Olympics' facility has been adjudged the most expensive sport complex in the world. The initial "construction budget was put at US\$12 billion, and subsequently rocketed up to US\$51 billion as a result of alleged kickbacks and embezzlement through corrupt construction contracts" (Masters, 2014). In the UK the Office of Fair Trading (OFT, 2009) fined 103 construction companies and firms in England and Wales for collusion with competitors to get building contracts. The investigation of the OFT (2009) into bidding and cover pricing, led to the imposition of fines totalling $f, 129.5 \mathrm{M}$ on various organisations, though this amount was subsequently reduced on appeal.

It is possible that the culture of organisations can explain differences in business behaviour and its meanings. A right business culture may help organisations to be morally upright, entrench good business ethics and above all help them to flourish profitability (Schein 1990). Thus, with allegations and evidence of construction organisations involvement in corrupt practices, there is need for thorough examination on whether the culture of organisations influences fraudulent practices.

\section{Literature Review}

There is a growing worldwide concern over high levels of corrupt activities among corporate organisations. Transparency International (TI, 2011) asserts that majority of construction businesses around the globe "are vulnerable to corruption ... and the industry is one of the most corrupt sectors in which to do business". In addition, notable reports such as the Chartered Institute of Building (CIOB, 2013) publication 'Exploring corruption in the UK Construction Industry' seem to corroborate the aphorism that the construction sector is corrupt. Unfortunately, despite widespread corruption allegations against the industry, research on the culture of construction organisations in relation to fraud and corruption has not received appropriate attention. Perhaps a combination of the theme culture and corruption is difficult to research due to the sensitive nature of both subjects. In addition, many businesses may be reluctant to partake in research concerning the subject, since they may not wish to be involved in anything that may damage reputations or curtail their activities. In some quarters, corruption is not considered a misdemeanour because it is seen as a necessary aspect of doing business (Hawley, 2000; GTIL, 2013).

Defining corruption is difficult and the underlying complexity in the definition of corruption stems from the fact that what may be perceived by one person to be corrupt is often considered common practice by another. For instance, research conducted by the Chartered Institute of Building (CIOB, 2013, p.3) shows that "around 25\% of their research participants felt that accepting or concealing bribes was either not very corrupt or not corrupt at all". Many definitions of corruption exist. However, the Institute of Internal Auditors (IIA, 2012) defines corruption as an act which takes place in the form of providing or soliciting illicit benefits; and it is hard to detect. Corrupt practice normally manifests itself as follows: bribery, embezzlement, extortion, influence peddling, unlawful gratuity, favour, commission, nepotism and illegal payments (OECD, 2013). Uneke (2010, p.43) argued that the culture of many western multinational organisations is hypocritical; "they are virtuous in the developed world and a bub for corrupt activities in developing countries". 
This assertion seems to uphold the UK Office of Fair Trading (OFT, 2009) fine of $f 2.25 \mathrm{M}$ on Balfour Beatty for alleged involvement in "payment irregularities" in the construction of the Great Library of Alexandria in Egypt. According to the OFT (2009) "the company's culture outside the shore of the UK fell below expectations".

\section{The culture of construction organisations and corruption}

There are varied perceptions concerning organisational culture and its influence over businesses. However, Human Factors International (HFI, 2011, p.3 claims that "most theorists agree that organisational culture exists, and that it has definite effects, but an explicit definition of its true nature eludes capture". Notwithstanding, an array of definitions of organisational culture exist. The most cited definition is proffered by Schein (1990, p. 116) who claimed that organisation culture is "a pattern of basic assumptions invented, discovered and developed by a given group as it learns to cope with its problems of external adaptation and internal integration that has worked well enough to be considered valid and is therefore taught to new members as the correct way to perceive, think about, and feel in relation to those problems". Nevertheless, regardless of theoretical definitions of organisational culture every organisation has a way of defining its culture to suit their way of operation. Many businesses see their organisational culture as:

- the company's philosophy

- company style of operation

- the way we do things around here

Zuo and Zillante (2005) argued that construction organisations have two broad cultures: the organisational culture and project culture. Gareis and Huemann (2000), claim that project culture is often underpinned by project objectives. In most cases, it is the project manager responsibility to shape a project culture that stimulates teamwork and high levels of personal motivation, as well as a capacity to quickly identify and resolve problems that threaten project work (Zuo and Zillante, 2005). Perhaps, it is necessary to strengthen project culture because of its potential to encourage corrupt practices at project level in the midst of complex supply chains. In addition, project culture can easily be corrupted due to vast amount of power entrusted in the hands of project managers; indeed, 'absolute power, they say, corrupts absolutely'. It is important to mention that the culture exhibited at project level is often a reflection of the leadership and organisational structure that is adopted for each project (Widemen, 2001).

Within the construction context, there are number of definitions regarding corruption, however they do not go on to measure or assess the role of organisations and project culture influence on corrupt practices in the industry. Anderson (2003) made efforts to measure the influence of project culture on overall project performance together with an assessment of culture at both the project level and the organisational level. The findings show that task-oriented culture is widely accepted as the most appropriate project culture, with direct influence on performance parameters such as functionality and participant satisfaction. Thus, there remains a gap in knowing whether project culture is more prone to fraud and corruption, compared to organisational culture.

While considerable variation exists about whether the culture of organisations within the construction influences corruption, research findings from TI (2006), OECD (2013) and CIOB (2013) portray that corruption and other fraudulent practices are more prevalent in preconstruction stages, especially in tendering stages. Soreide (2006, p.17) claimed that "the function of procurement procedures is a major source of corruption in the construction industry; with $42 \%$ of company executive officers claiming that they have reason to believe that competitors bad been influencing tender procedures unduly". Arguably, the issue of tendering, pre-construction and procurement of projects are strategic matters often dealt with at organisational levels. This may lead to a conclusion that corruption is possibly prevalent within organisational cultures. 
Subcontracting norms that dominate present day construction may serve to enhance corruption and other fraudulent practices. The reliance on subcontractors has put much stress on main contractor-subcontractor relationships and in such situations corruption may occur. Humphreys et al (2003) argued that main contractors have realised that the greatest potential for cost savings lies with the use of subcontractors; thus a situation where many segments of construction are subcontracted to other companies. The process of Dutch auctions may contribute to the corrupt practices in the industry, because it encourages unhealthy competition, underpinned by 'kickbacks' to project officers that award subcontracts (Stansbury, 2005).

Corruption perpetuated at project level may simply be referred to as 'bricks and mortar' corruption; because large volumes of construction components are often concealed by other elements. For example, most construction works such as block laying, plumbing and electrical installations are normally covered by brickwork, plasterboard or paint. Stansbury (2005) argues that the industry is one where an enormous number of inspections of materials are being completed on a daily basis, and supervision of work is dependent on contractors. Thus, once materials are covered it is very difficult and costly to check their authenticity and the quality of workmanship. This kind of culture may lead to the use of inferior materials and poor workmanship. The resultant effects can be seen from an increase in defective works and the number of collapsed buildings around the word.

The nature of construction projects in terms of complexity of schemes, tasks, costing/estimation of project elements, diverse procurement arrangements, contractual structure, diversity of skills, extent of government involvement in projects, concealed work, project phases, uniqueness of projects, size of projects and above all secrecy that surrounds projects appears to make corruption, fraud and other sharp practices possible (TI, 2006). Moreover, complex contractual structures for which the construction industry is known, that usually involves lengthy supply chains in the form of clients, consultants, main contractors, subcontractors, sub-subcontractors and suppliers appears to make the fight against corruption more difficult.

Stansbury (2005) argues that many construction projects (especially government owned schemes) are managed under strict price secrecy and industry norms simply encourage cost elements of projects (price of items) to be kept secret even when it is public money that is being spent. This means confidentiality normally takes precedence over public interest. This sort of culture does not only aid and abet corruption in the industry, it can make it undetectable.

A review of organisational culture and corruption cases show that the problem is multidimensional; in some cases leading to manipulation of project prices to secure contracts and to maximise profits. Some practitioners may not consider cover pricing as a corrupt practice, because there is no money changing hands. The Construction Manager Magazine (CM, 2013) affirms that corruption and unethical conduct by professionals during the construction phase are commonplace among major contractors. Unethical practices may include items such as false identification, ghost workers and inflation of workers' hours (time sheets). For example, CM (2013) report that an operations manager of Balfour Beatty, a major construction company in the UK, "was jailed for three years in October 2012 after he and two other managers defrauded the company of £165,000 by authorising payments to two bogus workers who were not employed by the company. The fraud ran over five years from November 2005 to March 2011 and involved creating 'ghost' employees and putting their personal details on the payroll. Time sheets were then created and signed off by the managers".

Other examples of high profile corruption cases in construction are: the Lesotho Highlands Water Project (LHWP) scandal in South Africa; the Abuja Airport runway expansion scam of 2010; the Unik Construction Engineering (pty) Limited water project embezzlement in Botswana; the Laxmi Narayan Construction fraud case in India; the China Hunan Construction Engineering Group Corporation corruption case; the BRUN-WAY Construction Inc fraud case in Canada and the recent allegation of corruption in the Winter Olympics in Sochi, Russia. These 
cases seem to have something in common; the schemes are mega projects, one-off and involve large organisations. These projects come at irregular periods; thus the tendency for large construction companies to hunt for such projects. Winning these types of projects may be critical to the survival and profitability of contractors involved; hence they provide an incentive for bribery and corruption (Darroch, 2007).

Government involvement in construction either as clients or industry regulators probably contributes to organisation's involvement in corrupt practices. Indeed, governments are clients to over $70 \%$ of construction and infrastructure projects around the world and even privatised schemes often require government approval for planning or an arrangement to pay end-product users (Stansbury, 2005). TI (2006, p.30) claimed that "numerous permits are often required, where there is insufficient control on how government officials behave. Thus, their power combined with the structural and financial complexity of the projects makes it relatively easy for officials to extract bribes". Politicians with influential positions in government may facilitate corruption, by awarding dubious construction contracts for personal gain or to fulfil political pledges.

However, fraudulent activities are not peculiar to construction organisations alone. The act cuts across many facets of life; for example those doing business in the oil and gas, transportation, aviation and medical industries are not exempted from the problem of corruption. So far, the world's largest corporate fine and fraud settle of $\$ 30 \mathrm{BN}$ is in the USA; where the Food and Drug Administration (FDA) prosecuted British pharmaceutical giant GlaxoSmithKline who pleaded guilty for failure to report safety data. The same company was "fined nearly $\$ 500$ million for bribery in Sept. 2014 by a Chinese court” for similar offences (Bradsher and Buckley, 2014).

\section{Corruption and rent-seeking theory}

Rent-seeking theory is one of the earliest theories that has been used to model corruption. The theory compares corruption to lobbying, and suggests that lobbying entails a waste of resources in the competition for preferential treatment. The traditional rent-seeking theory considers various forms of seeking preferential treatment by public decision makers for instance corruption and competitive lobbying as rent-seeking. Based on this insight a formal model was propounded by Tullock (1980) which states that there is rational to invest in rent-seeking as long as the marginal input is smaller to the potential output it generates. Therefore the resulting market equilibrium can be determined by a formal model. The model assumes that organisations compete for a monopoly created by a system. Though, this is questionable, for the theory to be purposeful the standard assumption is that all organisations take the rent $(\mathrm{R})$ to be given exogenously.

Lambsdorff (2001, p.102) stated that the theory further assumes that the probability for winning the competition (pi) is proportional to an organisation's investment in rent-seeking (xi). Given that this assumption applies to all firms equally and all probabilities must add up to one, a single organisation's probability decreases with the investments undertaken by its competitors. Thus, in the case of a number of organisations, this will result in:

$$
\mathrm{P} i=\frac{x i}{\sum i_{j} j^{j}}, i j j=1, \ldots, n
$$

with xi being the expenses for rent-seeking of organisations (i). The resulting equilibrium can easily be determined once assumptions are introduced that organisations are risk-neutral, act symmetrically and are unable to influence their competitors' level of rent-seeking (xj). Maximising the expected profit, $\mathrm{E}(\mathrm{PiR}-\mathrm{xi})$, then requires: 
$\frac{\mathrm{d}(\mathrm{P} i \mathrm{R}-\mathrm{xi})}{\mathrm{dx} i}=\frac{d\left(\frac{R x i}{\sum_{\mathrm{j}}^{i} \mathrm{x} j}-x i\right)}{d x i}=\frac{R}{\sum_{\mathrm{x} j}^{a}}-\frac{R x i}{\left(\sum_{\mathrm{xi}}\right)^{2}}-1=0$

Function (1) can be solved by introducing symmetry, $x i=x j=x$. This brings about the CournotNash-equilibrium and the following optimal level of rent-seeking:

$$
\frac{\mathrm{R}}{\mathrm{nx}}-\frac{R x}{\sum n^{2} x^{2}}=1 \Leftrightarrow n R-R=n^{2} x \Leftrightarrow x=\frac{n-1}{n^{2}} R
$$

Therefore, total expenses $(\mathrm{S})$ for rent-seeking then sum up to:

$$
\mathrm{S}=n x=\frac{n-1}{n} R
$$

The model assumes that as the number of firms (n) joining the competition increases, monopolistic rents increase and more resources (S) are devoted to wasteful lobbying. This demonstrates that competition increases waste (Lambsdorff, 2001). Arguably, the theory does not put organisation involvement in corrupt practice to bed; and as Thompson (1993, p.369) says "corruption is bad not because money and benefits change hands, and not because of the motives of participants, but because it privatises values aspects of public life, by-passing processes of representation, debate and choice".

This assertion seem to support Leff's (1964) view in his publication 'Economic Development through Bureaucratic Control' that corruption may be considered a useful substitute for a weak rule of law. This is insofar as a weak intransigent bureaucracy that is unable to make decisions may need corruption in order to progress a situation. Without corruption the wheels of business may just grind to a halt, particularly and arguably in under-developed countries. This proposition is further expounded by Houston (2007, pp.325-42). The overriding position must remain however; corruption is wrong, immoral and, in the majority of instances, illegal.

\section{Study Methodology}

The study present findings on whether the culture of construction organisations promotes corrupt practices in the UK construction industry. The main objective of the study is to identify whether the culture of construction organisations supports corrupt practices in the construction industry. The study employed mixed research methods; and includes the examination of five case studies to facilitate in-depth examination of the research problem. The multi-methods research design employed QUAL-QUAN concept; this means that data are collected using both qualitative and quantitative methods. However, the qualitative method is the lead data collection instrument, whilst quantitative collected data are used to support and validate the qualitative findings. The study data collection includes use of structured interviews and a questionnaire survey. The data was collected between July 2013 and February 2015.

\section{Structured interviews}

A non-probability and purposive sampling method was adopted for interviews. Eleven professionals with 13 to 22 years of working experience in the construction industry and other related disciplines were interviewed. The interviewees were from the private sector, public sector, quasi-government organisations and other stakeholders such as Transparency International. All were based in the UK. The interview questions were pilot-tested with an architect, engineers, quantity surveyors and academics in UK universities. The purpose of the pilot study was to ascertain whether questions and instructions were clear and unambiguous and if participants found the questions appropriate. Questions that were improper were 
removed or reconstructed. Study participants preferred to remain anonymous as most of the questions were sensitive. As a precaution, all information linked to individuals and organisations that participated in the study, was removed. The interview data were subsequently analysed using Nvivo 10 software to filter and sort findings. Five case studies concerning high profile corruption cases linked to construction giants in five countries: Canada, France, Nigeria, the United States of America and Turkey, were subsequently analysed.

\section{Questionnaire survey}

The questionnaire was also pilot-tested to determine whether the measurement instrument was clear. A stratified random sample was used. This was to ensure that sample adequately represents selected groups in the population. First, the study population was classified into strata (groups) on the basis of common characteristics such as the profession and nature of work experience relating to the construction industry. The population was also divided into four main groups using: size of company, firm, partners, government agencies and others as a guide. Group 1 targeted senior managers of large construction companies, Group 2 focused on directors of SMEs doing business in the construction industry, Group 3 consultants and Group 4 captured senior managers of government and other agencies such as the anticorruption agency - Transparency International.

One hundred and thirteen copies of the questionnaire were prepared and distributed among the targeted sample; administered either by hand or through e-mails. A total of 42 questionnaires were received from participants and deemed valid as shown in Table 1. Using formula put forward by Neumann (2000) the active response rate was calculated as $37.17 \%$. Easterby-Smith et al (2006, p.96) claim that "if measured appropriately; within the construction industry a 25 to 30\% response rate is considered acceptable".

Since the questionnaire data were obtained from four different groups, Mann-Whitney two group post-hoc tests for homogeneity; were conducted using SPSS. The test result shows that Mann-Whitney (U), Asymp. Sig. (2-tailed) for Group 1 against Group 2 to be $=0.72$; Group 1 against Group 3 = 0.81; Group 2 against Group 3 = 0.64; and Group 3 against Group 4 (Gp 4) $=0.51$. These $(\mathrm{U})$ values show that there no significant difference between data obtained from different sources.

Table 1: Category of participants and valid questionnaires considered by the study

\begin{tabular}{|l|l|l|l|}
\hline $\begin{array}{l}\text { Category of companies and } \\
\text { clients in construction } \\
\text { involved in the study }\end{array}$ & $\begin{array}{l}\text { Total number of } \\
\text { questionnaires sent to } \\
\text { participants }\end{array}$ & $\begin{array}{l}\text { Total number of valid } \\
\text { questionnaires received } \\
\text { from participants }\end{array}$ & $\%$ response \\
\hline $\begin{array}{l}\text { Major construction companies } \\
\text { (including service providers) }\end{array}$ & 74 & 27 & 36.49 \\
\hline Firms and partners & 17 & 6 & 35.29 \\
\hline Government agencies & 22 & 9 & 40.91 \\
\hline Total & 113 & 42 & 37.17 \\
\hline
\end{tabular}

\section{Analysis and Findings}

\section{Questionnaire data key assumptions}

The main criticism from the pilot-tested questionnaire was: does the study expect interviewees to base their answers on rumour, deductions from uncertain facts or their involvement in corrupt acts. This is imperative considering the facts that the subject is sensitive and participants may be 
reluctant to give the truth. This was factored into the final reconstructed questionnaire and it was clearly stated that interviewees were to make their judgements on their best knowledge of their organisations, and their personal experiences. Based on this key assumption, when study participants were asked 'if they believe that their companies had at one time or the other been involved in any act capable of been identified as bribery or corruption in order to get lucrative contracts?', $13 \%$ very strongly agree, $46 \%$ strongly agree; $8 \%$ agree with remaining participants either disagreeing or unsure as shown in Figure 1.

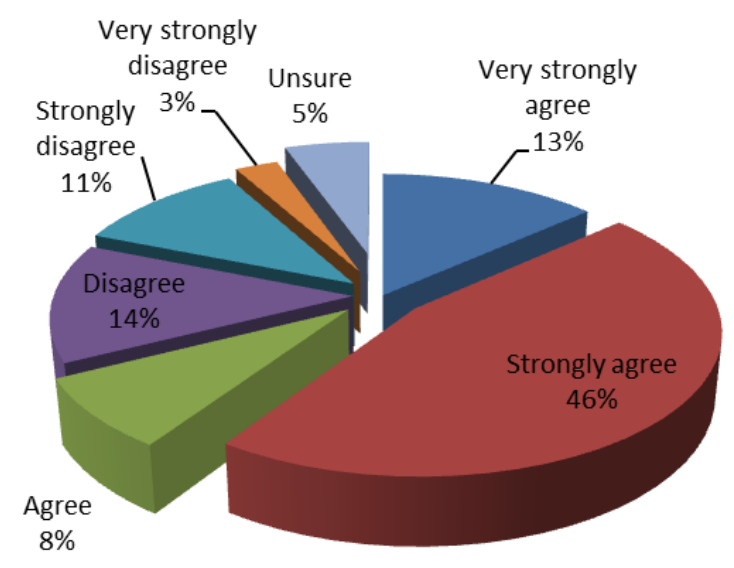

Figure 1: Participants' view on construction organisations' involvement in corrupt practices

Table 2 shows the percentage of participant agreement to common types of fraud/corrupt activities in the UK construction industry. The study reveals that $31 \%$ of participants agree that 'kickbacks' to project officers or their representatives is the most commonest type of fraud/corrupt activity; followed by manipulation of tendering processes with $24 \%$. 'Shady' subcontracting 19\%; bid rigging / cover pricing 18\%; bribing of project officers $6 \%$, and; falsification of documents $2 \%$. By implication, this means that most corrupt activities takes place at strategic levels in the industry.

Table 2: Percentage of common types of fraud/corrupt activities in construction

\begin{tabular}{|l|c|}
\hline $\begin{array}{l}\text { Common types of fraud/corrupt activities in the UK } \\
\text { construction industry }\end{array}$ & $\begin{array}{l}\text { Percentage of participants that judge this } \\
\text { type of fraud most common in the } \\
\text { construction industry }\end{array}$ \\
\hline 'Kickbacks' to project officers or their representatives & 31 \\
\hline Manipulation of tendering processes & 24 \\
\hline 'Shady' subcontracts & 19 \\
\hline Bid rigging/ cover pricing & 18 \\
\hline Bribery of project officers to get subcontracts & 6 \\
\hline Falsification of documents & 2 \\
\hline Total & 100 \\
\hline
\end{tabular}

\section{Interview data key assumptions}

Similar assumptions made in the questionnaire data above were also considered in the collection of interview data. The interviews were recorded using a digital recorder and subsequently transcribed for clear interpretation. Some textual contents of the interview data were trimmed from the transcribed data for better understanding and spontaneity of the interaction between the lead researcher and study participants. For instance, when participants were asked to express their view concerning construction's involvement in fraud and corrupt practices, their responses raised notable issues concerning the study theme. Some of the textual excerpts are highlighted as follows: 
... lobbying for contracts is a common business tactic, ... though I have my own reservation about our dealings with some construction companies ... in recent times corruption is fast becoming an inevitable factor (Director in Local Government Authority - UK).

... the norms in the industry itself promote dishonesty ... the competition out there is stiff ... these organisations have to play the game otherwise the smart folks, will make their business redundant (Project Manager for large construction company).

Moreover, interviewees were asked to identify key organisational culture features in the construction industry that promote fraud and corruption. Below are some of the excerpts:

... everything about the industry, I mean everything about construction encourages corruption ... the nature of the industry itself, unnecessary competition from rivals, the politics of hunting for contracts down to nature of clients out there ... when you talk about corruption in construction, ... we need to bear in mind that it is a tough industry and purely a client-led industry. Most businesses will do anything to buy favour from clients. They say 'be who plays the piper dictates the tune' ... it is obvious that large scale corruption normally involves people in authority; the record is there for all to see. As a researcher have you heard of any high profile corruption cases without big boy's involvement? (Construction Manager in a large construction company).

...tendering processes in construction seem to fall short of expected standards ... the culture of subcontracting ... together with the nature of most projects normally brings about unhealthy internal competition ... in many countries there is a kind of cartel culture between few large construction organisations and they often set standards to determine what they want ... this sort of norm often gives undue advantage to large companies when it comes to securing huge government contracts.... Moreover, we cannot take away lobbying for contracts from these [sic] companies ... this is what makes the industry work. (Senior Partner-QS and Cost management firm)

Table 3: Case studies of corruption involving major construction companies

\begin{tabular}{|c|c|c|c|c|}
\hline & $\begin{array}{c}\text { Name of organisations, country and } \\
\text { nature of corruption }\end{array}$ & Year & $\begin{array}{c}\text { Case } \\
\text { outcome }\end{array}$ & $\begin{array}{l}\text { Organisational behaviour that led } \\
\text { to fraud and corruption }\end{array}$ \\
\hline 1 & $\begin{array}{l}\text { Bouygues, Suez-Lyonnaise and Vivendi } \\
\text { Corrupt Cartel in France (Nature of } \\
\text { charges: fraud and corruption). }\end{array}$ & $\begin{array}{c}1998- \\
2005\end{array}$ & $\begin{array}{l}\text { Prosecution } \\
\text { and fine. }\end{array}$ & $\begin{array}{l}\text { Misappropriation of public funds; } \\
\text { 'kickback' to government officers and } \\
\text { complex contractual arrangements. }\end{array}$ \\
\hline 2 & $\begin{array}{l}\text { Construction contract scandal involving } \\
\text { several projects and building companies } \\
\text { in Turkey (Nature of charges: fraud and } \\
\text { corruption). }\end{array}$ & $\begin{array}{c}2014- \\
2015\end{array}$ & $\begin{array}{l}\text { Allegation, } \\
\text { still under } \\
\text { investigation. }\end{array}$ & $\begin{array}{l}\text { Fraudulent award of contracts; undue } \\
\text { fraternity between representative of } \\
\text { construction organisations and } \\
\text { government officers; high level } \\
\text { lobbying for contracts; use of } \\
\text { unscrupulous companies and } \\
\text { manipulation of tender processes. }\end{array}$ \\
\hline 3 & $\begin{array}{l}\text { Dantata and Sawoe Ltd, 'Kickback' } \\
\text { payment of N1.3 Billion involving high } \\
\text { profile government officer in Nigeria } \\
\text { (Nature of charges: fraud and } \\
\text { corruption). }\end{array}$ & $\begin{array}{l}\text { Jun- } \\
2014\end{array}$ & $\begin{array}{l}\text { Allegation, } \\
\text { still under } \\
\text { investigation. }\end{array}$ & $\begin{array}{l}\text { The use of fraudulent subcontractors, } \\
\text { owned by government officers; lack of } \\
\text { transparent tendering processes; } \\
\text { monthly valuation manipulated to } \\
\text { influence payment to companies and } \\
\text { inflated project estimates. }\end{array}$ \\
\hline 4 & $\begin{array}{l}\text { Balfour Beatty Plc, Bribery and } \\
\text { Accounting Fraud Scandal involving } \\
\text { State of Delaware, United States (Nature } \\
\text { of charge: fraud). }\end{array}$ & $\begin{array}{l}\text { May } \\
2013\end{array}$ & Prosecution. & $\begin{array}{l}\text { Evidence of fraudulent and complex } \\
\text { contractual arrangements; cartelising } \\
\text { bidding processes and undue payment } \\
\text { from organisation' accounts. }\end{array}$ \\
\hline 5 & $\begin{array}{l}\text { The Charbonneau Commission, Canada: } \\
\text { Public Contracts scam involving several } \\
\text { construction companies (Nature of } \\
\text { charges: fraud and corruption). }\end{array}$ & $\begin{array}{l}\text { Oct. } \\
2011\end{array}$ & $\begin{array}{l}\text { Prosecution } \\
\text { and fine. }\end{array}$ & $\begin{array}{l}\text { Bid rigging, cartels, manipulation of } \\
\text { contract prices, tendering processes, } \\
\text { rates and undue relations between } \\
\text { government officers and construction } \\
\text { contractors. }\end{array}$ \\
\hline
\end{tabular}


Apart from questionnaire and interview data, five case studies were scrutinised to provide indepth and practical understanding on how organisational culture influences corruption in the construction industry. The extracts from the five case studies concerning alleged high profile corruption cases involving construction companies in five countries were examined and are presented in Table 3.

Table 4 illustrates summary of construction organisational behaviour captured from five case studies concerning high profile corruption cases; in addition to themes recorded by Nvivo 10 when participants were asked to enumerate key construction organisational cultures that encourages fraud and corruption in construction.

Table 4: Summary of organisational culture that encourages fraud and corruption

\begin{tabular}{|c|c|c|c|c|c|}
\hline $\begin{array}{l}+ \text { and - } \\
\text { cultural } \\
\text { practices }\end{array}$ & $\begin{array}{c}\text { Organisational cultural } \\
\text { theme }\end{array}$ & Frequency & $\begin{array}{c}+ \text { and }- \\
\text { cultural } \\
\text { practices }\end{array}$ & $\begin{array}{c}\text { Organisational cultural } \\
\text { theme }\end{array}$ & Frequency \\
\hline+ & $\begin{array}{l}\text { Lobbying for contracts and } \\
\text { attempts to out-perform } \\
\text { competitors sometimes brings } \\
\text { about corrupt practices in } \\
\text { industry. }\end{array}$ & 4 & - & $\begin{array}{l}\text { Poor remuneration of } \\
\text { employees is common } \\
\text { practices }\end{array}$ & 2 \\
\hline - & $\begin{array}{l}\text { The culture of construction } \\
\text { organisations challenges } \\
\text { competing value frameworks }\end{array}$ & 1 & - & $\begin{array}{l}\text { The culture of low profit } \\
\text { margins encourages } \\
\text { institutional corruption. }\end{array}$ & 1 \\
\hline - & $\begin{array}{l}\text { The culture focuses more on } \\
\text { 'getting things done through } \\
\text { people'. }\end{array}$ & 2 & + & $\begin{array}{l}\text { The culture of tendering } \\
\text { for jobs gives } \\
\text { opportunities for } \\
\text { corruption. }\end{array}$ & 4 \\
\hline- & $\begin{array}{l}\text { Inability to innovate the use } \\
\text { of electronic payment systems } \\
\text { for construction project } \\
\text { transactions. }\end{array}$ & 5 & - & $\begin{array}{l}\text { Transparency often scarce } \\
\text { in tendering processes. }\end{array}$ & 6 \\
\hline - & $\begin{array}{l}\text { The industry is heavily client- } \\
\text { led, thus the tendency for } \\
\text { contractors to 'dance to the } \\
\text { tune' of most clients. }\end{array}$ & 4 & + & $\begin{array}{l}\text { Secrecy of prices and rates } \\
\text { often common practice } \\
\text { among construction } \\
\text { organisations. }\end{array}$ & 2 \\
\hline - & $\begin{array}{l}\text { Lack of institutional and } \\
\text { strong ethics enforcement } \\
\text { from professional bodies in } \\
\text { industry. }\end{array}$ & 1 & - & $\begin{array}{l}\text { Culture of lowest bidder } \\
\text { often encourages corrupt } \\
\text { practices. }\end{array}$ & 3 \\
\hline - & $\begin{array}{l}\text { The culture allows 'all comers' } \\
\text { with little or no professional } \\
\text { training; few barriers to entry. }\end{array}$ & 2 & + & $\begin{array}{l}\text { Lobbying for high value } \\
\text { contracts is a common } \\
\text { cultural practice }\end{array}$ & 5 \\
\hline+ & $\begin{array}{l}\text { The pervasive use of } \\
\text { subcontractors and } \\
\text { consultants. }\end{array}$ & 6 & + & $\begin{array}{l}\text { Payments to contractors } \\
\text { heavily depends on QS } \\
\text { valuation methods. }\end{array}$ & 2 \\
\hline- & $\begin{array}{l}\text { Complex contractual } \\
\text { arrangements by } \\
\text { organisations. }\end{array}$ & 3 & - & $\begin{array}{l}\text { Most construction } \\
\text { organisations operate } \\
\text { weak record management } \\
\text { systems. }\end{array}$ & 4 \\
\hline- & $\begin{array}{l}\text { culture of inaccurate project } \\
\text { estimates; arguably tends to } \\
\text { encourage corruption. }\end{array}$ & 2 & - & $\begin{array}{l}\text { Informal payments' } \\
\text { culture common among } \\
\text { small businesses in the } \\
\text { industry. }\end{array}$ & 3 \\
\hline- & $\begin{array}{l}\text { the culture of some } \\
\text { organisations encourages } \\
\text { cover-up of wrong doings; } \\
\text { thus whistle-blowing is scarce } \\
\text { in the sector. }\end{array}$ & 3 & - & $\begin{array}{l}\text { Cartel sort of culture may } \\
\text { sometimes exist among } \\
\text { large companies. }\end{array}$ & 5 \\
\hline
\end{tabular}




\section{Conclusion}

A deduction from the study is that tackling corruption among organisations is difficult because there are discernible benefits to those who partake in corrupt activities; at least in an economic sense. The nature and traits of fraud and corruption show that the act is closely linked to culture, organisation values and beliefs that people hold. Arguably, the way construction organisations operate tends to make them vulnerable to corrupt practices. The culture of most construction organisations is such that the use of lengthy supply chains and complex contractual arrangements are customary. Moreover, negotiation for commercial interests and complex contract arrangements are common practice in the construction and infrastructure sector. Thus, there is the possibility for clients, consultants, contractors and suppliers to leverage payments or other benefits for organisational or private gain.

There are polarised views about what constitutes corrupt activities and the extent of corruption in the construction industry. However, findings from the study show that the culture of construction organisations, together with the nature of the industry, may facilitate fraud and corruption. The study also reveals that the pervasive use of subcontractors and consultants, the lack of transparency in tendering processes, lobbying for contracts, cover pricing and cartels, among other factors, may support fraud and corruption in an institutionalised manner. Examination of five high profile fraud and corruption cases shows that fraudulent award of subcontracts, use of unscrupulous companies, lack of transparency in tender processes and cartels by mainly large organisations, are cultural practices that fuel corruption. Over $60 \%$ of the study participants claim that they have reason to believe that their organisations had at one time or the other acted in a corrupt manner.

\section{References}

Anderson, E.S., 2003. Understanding your project organization's character. Project Management. 34(4), pp.4-11.

Bradsher, K. and Buckley, C., 2014. China Fines GlaxoSmithKline Nearly \$500 Million in Bribery Case. New York Times. Available at: www. nytimes.com/2014/09/20/business/international/gsk-china-fines.html?_r=0. [Accessed 07 July 2015].

Calkins, L.B., 2009. KBR Halliburton Agree to $\$ 579$ Million Fine for Nigeria Bribes. Bloomberg Money News Available at: www. Bloom berg.com/apps/news?pid=newsarchive\&sid=a 5SIJHgE3rXA. [Accessed 07 July 2015].

CIOB, 2013. A Report Exploring Corruption in the UK Construction Industry. The Chartered Institute of Building. September, 2013.

CM, 2013. Corruption: A bad reflection of the industry. Construction Manager Magazine. Available: http://www.construction-manager.co.uk/agenda/corruption-bad-reflection-industry/ Accessed 14 August 2015.

Darroch, F., 2007. "Lesotho Highlands Water Project: corporate pressure on the prosecution and judiciary" in Global Corruption Report 2007, Berlin: Transparency International. Available at: www.transparency. org/publications/gcr. Accessed 07 August 2015.

Dunde, D.F, Hameed, S. and Magpile, J., 2014. The Costs of Corruption: Strategies for ending a tax on private-sector led growth. The Center for Strategic and International Studies; p.2.

Easterby-Smith, M., Thorpe, R., and Lowe, A., 2006. Management Research, an Introduction. SAGE Publications, London, United Kingdom.

Ernst and Young, 2012. Managing bribery and corruption risks in the construction and infrastructure industry. EYGM Limited publication an Assurance, Tax, Transactions Advisory company; pp. 1 -2.

Gareis, R. and Huemann, M., 2000. Project management competences in the project based organization. In Turner, J.R., Simister, S.J. and Lock, D., eds. The Gower Handbook of Project Management, 3rd edition. Aldershot: Gower.

Gates K and L, 2014. Biggest Risk of Corruption in The Construction Industry: The Global picture. K\&L Gates LLP publication London.

GTIL, 2013. Time for a new direction: Fighting fraud in Construction. The Grant Thornton International Ltd. Available on http://www.uzgt.uz/Fighting\%20fraud $\% 20$ in $\% 20$ Construction $\% 20$ A4\%20online $\% 20$ version.pdf.

Harinarain, N, Bornman, C L and Botha, M., 2013. Organisational culture of the South African construction industry Acta Structilia. Available at: http://www.ajol.info/index.php/actas/issue/view/10419 Accessed 08 August 2015.

Hawley, S., 2000. Exporting corruption; Privatization, Multinationals and Bribery. The Corner House Magazine, June; pp.2-6. 
HFI, 2011. An Introduction to the Organisational Culture Questionnaire (OCQ). Human Factor International Publication, p. 3.

Houston, D.A., 2007. “Can Corruption Ever Improve an Economy”? Cato Journal. 27( 3), pp.325-42.

Humphreys, P., Matthews, J. and Kumaraswamy, M., 2003. Pre-construction project partnering: from adversarial to collaborative relationships, Supply Chain Management: The International Journal, 8(2), pp.166-78.

IIA, 2012. Auditing for Corruption in Emerging Markets: Applying fraud detection skills to reduce corruption. The Institute of Internal Auditors Newsletter, p.2.

Lambsdorff, J.G., 2001. Corruption and rent-seeking. Kluwer Academic Publishers: Netherlands.

Leff, N.H., 1964. Economic Development Through Bureaucratic Corruption. American Behavioural Scientist, 8.November. Sage Publications Inc. pp.8-14.

Levine, D P., 2005. The Corrupt Organization. "Human Relations Journal". 58(6), p.24. doi: http://dx.doi.org/10.1177/0018726705057160

Masters, J., 2014. FIFA at the crossroads: Where does football turn next? CNN Business News. Available at: http://edition.cnn.com/2014/ 12/12/ sport/jeffrey-webb-fifa/index.html. [Accessed 07 July 2015].

Neumann, W. L., 2000. Social Research Methods: Qualitative and Quantitative Approaches. Allyn \& Bacon, New York, United States.

OECD, 2013. Clean Govbiz. Integrity in Practice. Available at: www.cleangovbiz.org. [Accessed 17 April 2014].

OFT, 2009. Construction industry in England: bid-rigging. The Office of Fair Trading (OFT). Available at https://www.gov.uk/cma-cases/construction-industry-in-england-bid-rigging Available at: 7 August 2015.

Runde, D.F, Hameed, S. and Magpile, J., 2014. The Costs of Corruption: Strategies for Ending a Tax on Private-sector led Growth. The Center for Strategic and International Studies. Lanham: Rowman \& Littlefield.

Schein, E. H., 1990. Organizational culture. American Psychologist, 45, 109-119. doi: http://dx.doi.org/10.1037/0003066X.45.2.109

Søreide, T., 2006. Is it wrong to rank? A critical assessment of corruption indices. WP 2006:1. Chr. Michelsen Institute; pp.13 $-17$.

Stansbury, N., 2005. Exposing the foundations of corruption in construction. Global construction report 2005; special focus on corruption in construction and post-conflict reconstruction. Transparency International, pp.36-48.

Thompson, D.F., 1993. Mediated corruption: The case of the Keating five. American Political Science Review, 87, pp.369-81. doi: http://dx.doi.org/10.2307/2939047.

TI, 2006. The Role of Transparency International in Fighting Corruption in Infrastructure. Annual Bank Conference on Development Economics, Tokyo, 29-30 May 2006. Rethinking Infrastructure for Development.

TI, 2011. Clear evidence of bribery between private companies. Transparency International Bribe Payers Index.

Tullock, G., 1980. Rent seeking as a negative-sum game. In Buchanan, J.M., Tollison, R.D. and Tullock, G. eds. Toward a theory of the rent-seeking society. pp.16-36. College Station: Texas A\&M University Press.

Uneke, O., 2010. Corruption in Africa South of the Sahara: Bureaucratic Facilitator or Handicap to Development? "The Journal of Pan African Studies", 3(6), 11.

Widemen, M., 2001. Managing the Project Environment. Available at: www.maxwideman.com/papers/projen viron/projenviron.pdf). [Accessed 23 June 2010].

Zuo, J. \& Zillante, G., 2005. 'Project Culture Within Construction Projects: A Literature Review' In:, 13th Annual Conference of the International Group for Lean Construction. Sydney, Australia, 19-21 Jul 2005. pp 353-361 